\title{
Enzyme Unit per Liter
}

National Cancer Institute

\section{Source}

National Cancer Institute. Enzyme Unit per Liter. NCI Thesaurus. Code C147130.

Unit of catalytic activity concentration defined as activity equal to one enzyme unit per one liter of system volume. 